\title{
Batik Jambi Promotion Based on Social Media in Asean Economics Community
}

\author{
Dahmiri, Sigit Indrawijaya, Raja Sharah Fatricia and Anita Yasmin \\ Faculty of Economics and Business, Jambi University, Jambi City, Indonesia
}

\begin{abstract}
Purpose - The aim of this study is to analyze the influence of social media-based promotion (personal relevance, interactivity, message, brand familiarity) to consumer purchasing decision of Batik Jambi in the Asean Economic Community (AEC) era.

Design/Methodology/Approach - The sample in this study amounted to 90 people. The type of research used is explanatory research. The hypothesis itself were tested with multiple linear regression equations using the tool SPSS 21.0 for Windows.

Findings - The results of this research in which the variable of personal relevance, interactivity, message, and brand familiarity are able to explain the variable of purchasing decision is equal to $82.9 \%$. Variables of personal relevance, interactivity, message, and brand familiarity have a significant influence on purchasing decisions either partially or simultaneously, while the message has a more dominant influence on purchasing decisions.
\end{abstract}

Research Limitations/Implications - The model significantly explains all the variables but in the future needs more testing for other variables to make the model more precise.

Practical Implications - The most dominant influence of social media-based promotional variables (personal revelance, interactivity, messege, brand familiarity) on consumer purchasing decision of Jambi's Batik in Jambi City are analyzed.

Originality/Value - Increasing understanding about social media-based promotions to consumer purchasing decisions on Jambi's Batik in AEC era.

Keywords Batik Jambi, personal relevance, interactivity, message, brand familiarity

All papers within this proceedings volume have been peer reviewed by the scientific committee of the Malikussaleh International Conference on Multidisciplinary Studies (MICoMS 2017).

\section{Introduction}

Batik Jambi faces a serious challenge today because of the enactment of Asean Economic Community (AEC), so it needs further study on the readiness of Jambi Batik industry in the competition in the era of AEC. One of them is to follow the development of information technology in social media which is used by various companies to promote their products.

(C) Dahmiri, Sigit Indrawijaya, Raja Sharah Fatricia, Anita Yasmin. Published in the Emerald Reach Proceedings Series. Published by Emerald Publishing Limited. This article is published under the Creative Commons Attribution (CC BY 4.0) licence. Anyone may reproduce, distribute, translate and create derivative works of this article (for both commercial and non-commercial purposes), subject to full attribution to the original publication and authors. The full terms of this licence may be seen at http://creativecommons.org/licences/by/4.0/legalcode

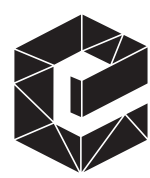

Emerald Reach Proceedings Series Vol. 1 
Proceedings of MICoMS 2017
Social media is an element of promotion mix, and this has a wide range so that companies can promote their products to all segments of society (Mangold and Faulds, 2009). Companies take advantage of social media because it is a promotional media that directly leads to consumers and involves direct interaction with consumers.

In this modern age, social media is not only used as a medium of communication, but also as a promotional medium because it offers many advantages (Rahadi and Abdillah, 2013). used as an interactive marketing tool, service, and building relationships with customers

and prospective customers (Siswanto, 2013).

In meeting the demands of consumer needs, many batik shops in the city of Jambi who already use social media as a means of marketing communication. This is because promotion through social media is considered very effective because it directly leads to the consumer and involves direct interaction with consumers. In addition, research on the promotion of social media especially related to Jambi batik has never been done. This phenomenon is interesting to be studied, especially the influence of social media-based promotion of purchasing decision of Jambi's Batik in Jambi City.

\section{Review of the Literature}

\subsection{Social Media-Based Promotions}

Social media is content that contains information created by people who use technology for publishing, it is very accessible and is meant to facilitate communication, influence, and interaction with others, and with the public in general (Thoyibie, 2010). Today, marketing practices through social media are beginning to evolve and used as a marketing tool for promoting brands of a company.

Social media is a means for consumers to share text, images, audio, and video information with each other (Kotler and Keller, 2009). Social media allows marketers to shape public perceptions and presence on the web as well as strengthen other communication activities.

The following are social media-based promotional factors (Kotler and Keller, 2009):

(1) Personal Relevance

In the use of social media as a promotional medium, social media brand accounts represent the identity of the brand. To that end, the brand needs to build personal relationships with consumers and pay attention to relevant content to consumers. The smart way to grow personal relevance is to use interesting words in social media.

(2) Interactivity

Interactivity is the characteristic of interfaces in the form of interaction between producers and consumers that influence consumer perception of information (Ronomenggolo, 2013).

(3) Message

Messsage or messaging factor is very important in making an internet advertisement. In promotion through social media, messages are information about products that can attract the attention of consumers.

(4) Brand Familiarity

Brand familiarity refers to the extent to which consumers have direct or indirect proximity to the brand (Allen et al., 2009). 
(5) Purchasing Decision

Purchasing decisions are the stage in the buyer's decision-making process in which the consumer actually buys (Kotler and Keller, 2009). Decision making is an individual activity that is directly involved in obtaining and using the goods offered. There are five stages in the purchase decision process: need recognition, information search, evaluation of alternative, purchase decision, and postpurchase behavior.

There are two indicators of purchasing decisions (Kotler and Keller, 2009):

(a) Having many advantages, the products offered to consumers have the advantage of competitors, both in terms of quality and facilities offered as well as various promos offered.

(b) Comprehensiveness of products, products that already have diversity, complete, and product updates.

\section{Method}

The population in this study are consumers who have purchased Jambi Batik online through social media. Since the population in this study is not known in number, the sample size in this study refers to the theory proposed by Hair et al. (1995) which recommends the minimum sample size is five times the number of question items contained in the questionnaire. The total question in this study is 18 questions, so the number of samples taken in this research is 90 respondents.

The type of research is explanatory research. Explanatory research is a research conducted to explain the causal relationship between research variables through hypothesis testing (Singarimbun and Effendi, 2012). The research approach used in this study is quantitative approach.

This study used multiple linear regression analysis with SPSS (Ghozali, 2011). The model in this research is:

$$
\begin{aligned}
Y & =a+b_{1} X_{1}+b_{2} X_{2}+b_{3} X_{3}+b_{4} X_{4}+e \\
Y & =\text { dependant variable (purchasing decision) } \\
a & =\text { constant } \\
b_{1} & =\text { coefficient of personal relevance variable } \\
b_{2} & =\text { coefficient of interactivity variable } \\
b_{3} & =\text { coefficient of message variable } \\
b_{4} & =\text { coefficient of brand familiarity variable } \\
e & =\text { error term } \\
X_{1} & =\text { personal relevance } \\
X_{2} & =\text { interactivity } \\
X_{3} & =\text { message } \\
X_{4} & =\text { brand familiarity }
\end{aligned}
$$

\section{Results and Discussion}

\subsection{Statistical Test Results}

From the result of the test, it is found that the data in this study is normally distributed, it is proved from the result of significance value (Asymp Sig. two tailed) greater than 0.05 , that is $(0.560>0.05)$ so it can be concluded that the data in this study is normally distributed. 
Proceedings of 4.2. Hypothesis Testing

MICoMS 2017 1. Regression equation

In accordance to the results of the research in Table 1, obtained multiple linear regression equation, namely:

$$
Y=6.053+0.388 \cdot \mathrm{X} 0.269 . \mathrm{X}_{1+2+3}+0.469 \mathrm{X} 0.468 X^{4+\mathrm{e}}
$$

\section{6}

a. Value constant $=6.053$

Positive constant value indicates the positive influence of independent variables (personal relevance, interactivity, message and brand familiarity), meaning that if the variable independent tends to be constant or not implemented properly then the value of the purchase decision is for 6.053 scale/unit.

b. Personal relevance $\left(\mathrm{X}_{1}\right)=0.269$

A Personal relevance variable regression coefficients $\left(X_{1}\right)$ of the purchase decision variable $(Y)$ has a meaning that each additional personal relevance value will raising the value of the purchase decisions of 0.269 , or in other words when the personal relevance could be improved by 1 unit, then it will be followed by an increase in purchasing decisions by 0.269 .

\section{c. Interactivity $\left(X_{2}\right)=0.388$}

Variable of interactivity is the regression coefficient $\left(X_{2}\right)$ of the purchase decision variable $(Y)$, which has a meaning that each additional interactivity value will increase the value of 0.388 purchasing decisions, or in other words when interactivity can be improved by 1 unit, then it will be followed by an increase of 0.388 product purchasing decisions.

\section{d. Message $\left(X_{3}\right)=0.468$}

Variable of message is the regression coefficient $\left(X_{3}\right)$ of the purchase decision variable $(Y)$, which has a meaning that each additional message value will raise the value of the purchase decisions of 0.468 , or in other words if the message delivered can be improved by 1 unit, then it will be followed by an increase in product purchasing decisions at 0.468 .

\section{e. Brand familiarity $\left(X_{4}\right)=0.469$}

Variable of brand familiarity is the regression coefficient $\left(X_{4}\right)$ of the purchase decision variable $(Y)$, which has a meaning that, each additional one brand familiarity value will

Table 1.

Regression Estimation Results

\begin{tabular}{|c|c|c|c|c|c|c|}
\hline & & \multicolumn{2}{|c|}{ Unstandardized Coefficients } & \multirow{2}{*}{$\frac{\text { Standardized Coefficients }}{\text { Beta }}$} & \multirow[b]{2}{*}{$T$} & \multirow[b]{2}{*}{ Sig. } \\
\hline \multicolumn{2}{|c|}{ Model } & Beta & Std. Error & & & \\
\hline 1 & (Constant) & 6.053 & 0.894 & & 6.768 & 0.000 \\
\hline & PerRel_X1 & 0.269 & 0.125 & 0.166 & 2.147 & 0.035 \\
\hline & Interactivity_X2 & 0.388 & 0.166 & 0.242 & 2.339 & 0.022 \\
\hline & Message_X3 & 0.468 & 0.152 & 0.289 & 3.080 & 0.003 \\
\hline & BrandFam_X4 & 0.469 & 0.170 & 0.291 & 2.765 & 0.007 \\
\hline
\end{tabular}


raise the value of the purchase decisions of 0.469 , or in other words when brand familiarity can be improved by 1 unit, then it will be followed by an increase in product purchasing decisions at 0.469 .

Batik Jambi Promotion in AEC

2. Test Results of the coefficient of determination $\left(R^{2}\right)$

The coefficient of determination is between 0 and 1 . If $R=0$ means that between independent variables (independent variables) and dependent variable (dependent variable) has no relation, whereas when $R=1$ means between independent variables (independent variables) and dependent variable (dependent variable) has a strong relationship.

The $R$ value of 0.911 indicates a double correlation (personal relevance, interactivity, message, and brand familiarity) with the purchase decision. Taking into account that the variations in value of $R^{2}$ of 0.829 , meaning that the percentage contribution of personal variables influence relevance, interactivity, message, and brand familiarity to the decision of purchase of products are amounted to $82.9 \%$, while the rest of $17.1 \%$ influenced by other variables that not included in this model.

\section{The F-Test Result (Simultaneous)}

The $F$-test basically shows does every free particles inserted into the model has simultaneous influence towards dependent variable or not. To examine the hypothesis, the $F$-test statistics was used trough the ANOVA table as it given in Table 3.

Based on the ANOVA test or the $F$-test, the $F_{\text {count }}$ generated was 77.476 with probability amount $P$-value 0.000 , because the level of significance is $<0.05(0.000<0.05)$ lower and because of that $H_{0}$ was rejected and $H_{1}$ was accepted, it can be concluded that the zero $\left(H_{0}\right)$ hypothesis was rejected and alternative hypothesis $\left(H_{1}\right)$ was accepted. This demonstrates that the variables (personal relevance, interactivity, message, and brand familiarity) simultaneously influence significantly towards purchasing decision variable of Batik Jambi.

\subsection{The t-Test Result (Partial)}

The purpose of this test was to examine does each variable appears independent towards the dependent variables (partial test). But other than that, this test was also conducted to find out which variable is more dominant in influencing customers purchasing decision.

(1) Personal Relevance $\left(X_{1}\right) t$-Test towards Purchasing Decision $(Y)$

Based on the regression test, the significant value obtained was 0.035 , because the significant level is $<0.05(0.035<0.05)$ so it can be concluded that personal relevance $\left(X_{1}\right)$ is influential towards purchasing decision of Batik Jambi, it means

\begin{tabular}{lcccc}
\hline Model & $R$ & $R^{2}$ & Adjusted $R^{2}$ & Std. Error of the Estimate \\
\hline 1 & 0.911 & 0.829 & 0.821 & 1.376
\end{tabular}

Table 2. Coefficient of Determination

\begin{tabular}{lcccccc}
\hline Model & & Sum of Squares & $d f$ & Mean Square & $F$ & Sig. \\
\hline 1 & Regression & 782.031 & 4 & 195.508 & 103.245 & 0.000 \\
& Residual & 160.958 & 85 & 1.894 & & \\
& Total & 942.989 & 89 & & &
\end{tabular}

Table 3.

The Simultaneous F-Test Result 
Proceedings of MICoMS 2017

\section{8}

there is liner relationship between personal relevance and purchasing decision of Batik Jambi $(Y)$.

(2) The Interactivity t-Test $\left(X_{2}\right)$ towards Purchasing Decision $(Y)$

Based on the regression test, the significant value obtained was 0.022 , because the significant level is $<0.05(0.022<0.05)$ so it can be concluded that interactivity $\left(X_{2}\right)$ is influential towards purchasing decision $(Y)$ of the product, it means there is linear relationship between interactivity $\left(X_{2}\right)$ and purchasing decision of Batik Jambi $(Y)$.

(3) The Message t-Test $\left(X_{3}\right)$ towards Purchasing Decision $(Y)$

Based on the regression test, the significant value obtained was 0.003 because the significant level is $<0.05(0.007<0.05)$ so it can be concluded that message $\left(X_{3}\right)$ is influential towards purchasing decision $(\mathrm{Y})$ of the product, it means there is linear relationship between message $\left(X_{3}\right)$ with purchasing decision of Batik Jambi.

(4) The Brand Familiarity t-Test $\left(X_{4}\right)$ towards Purchasing Decision $(Y)$

Based on the regression test, the significant value obtained was 0.007 , because the significant level is $<0.05(0.007<0.05)$ so it can be concluded that brand familiarity $\left(X_{4}\right)$ is influential towards purchasing decision $(Y)$ product, it means there is linear relationship between brand familiarity $\left(X_{4}\right)$ and purchasing decision of Batik Jambi $(Y)$.

Based on the aforesaid explanationof partial test it is known that every independent variable (personal relevance, interactivity, message, and brand familiarity) is influential towards dependent variable (purchasing decision). From the test conducted, it can be noted that message variable has bigger dominant influence compared with the other three variables.

\section{Conclusions and outlook}

This research concluded that the $R$-value shows multiple correlations (personal relevance, interactivity, message, and brand familiarity) with purchasing decision. With considering the variation of the $R$-square value as much as 0.829 , it means the contribution percentage of influence by variable personal relevance, interactivity, message, and brand familiarity towards product purchasing decision is as high as $82.9 \%$, while the $17.1 \%$ of it was influenced by another variables excluded in this model. The personal relevance, interactivity, message, and brand familiarity are simultaneously (altogether) and partially influential towards the purchasing decision of Batik Jambi. Message variable has the most dominant variable towards the purchasing decision of Batik Jambi compared to the other variables.

In accordance with the conclusion, the researcher would like to suggest for companies/ online shops to be more creative in creating new strategies and innovations in making advertising put in social media. Although the message factor is the main factor in consumer decision making of Batik Jambi, but it does not mean that other factors should be ruled out, considering that the variables are not something completely separated but rather a unity. In this case, of course it is necessary to maintain the continuity of these four factors while keeping the message factor as the main factor. This research needs to be followed up by examining the other more comprehensive factors.

\section{References}

Allen, B.S., Schumann, D.W. and Leingpibul, T. (2009). "Examining Brand Equity Antecedent/ Consequence Relationships". Journal of Marketing Theory and Practice, Vol. 17, No. 2, pp. 145-161. 
Dahmiri, Octavia, A. and Fatricia, R.S. (2017). "The Influence of Service Marketing Mix and Service Quality on Students' Satisfaction in Jambi University, Indonesia”. International Journal of Economics, Commerce and Management United Kingdom, Vol. V, No.6, pp. 398-414.

Ekasari, N. (2014). "Pengaruh Promosi Berbasis Sosial Media Terhadap Keputusan Pembelian Produk Jasa Pembiayaan Kendaraan Pada PT. BFI Finance Jambi”. Jurnal Penelitian Universitas Jambi Seri Humaniora, Vol. 16, No. 2, pp. 81-98.

Ghozali, I. (2011). Aplikasi Analisis Multivariate dengan Program SPSS 21.0. Undip, Semarang.

Hair, J.F., Anderson, R.E., Tatham, R.L., and Black, W.C. (1995). Multivariate Data Analysis (4th ed.). Prentice Hall International..

Kotler, P. and Amstrong, G. (2009). Prinsip-Prinsip Pemasaran. Alih Bahasa: Bob Sabran, MM. Edisi 12 jilid 1 dan 2. Erlangga, Jakarta.

Kotler, P. and Keller, K.L. (2009). Manajemen Pemasaran. Edisi 12, Jilid 1 \& 2, Terjemahan Benyamen Molan, PT.Indah, Jakarta.

Mahmudah, I.S. and Tiarawati, M. (2013). "Pengaruh Kualitas Produk, Citra Merek, dan harga Terhadap Keputusan Pembelian Pond's Flawless White". Jurnal Ilmu Manajemen, Vol. 1, No. 3, pp. 837-847.

Mangold, G. and Faulds, D. (2009). "Social Media: The New Hybrid Element of the Promotion Mix". Science Direct, Vol. 52, No. 1, pp. 357-365.

Rahadi, Rianto, D. and Abdillah L.A. (2013). "The Utilization of Social Networking as Promotion Media. (Case Study: Handicraft Business in Palembang)".Jurnal Sosial dan Informasi, Vol. 3, No. 1, pp. 1-6.

Ronomenggolo, S. (2013). Analisis Pengaruh Promosi Berbasis Sosial Media Terhadap Keputusan Pembelian Konsumen (Studi Kasus Produk ROVCA).

Singarimbun, M. and Effendi, S. (2012). Metode Penelitian Survey. LP3AES, Jakarta.

Siswanto, T. (2013). "Optimalisasi Sosial Media Sebagai Skripsi. Fakultas Ekonomi Universitas Hasanuddin. Media Pemasaran Usaha Kecil Menengah”. Jurnal Liquidity, Vol. 2, No. 1, pp. 8086.

Thoyibie, L. (2010). "Psikologi Social Media”. Available: http://komunikasi-indonesia.org., (accessed 12 January 2017).

\section{Corresponding author}

Dahmiri can be contacted at dahmiri@unja.ac.id 